\title{
Effect of alternating anaerobic and aerobic phases on the performance of a SBR treating effluents with high salinity and phenols concentration
}

E. Ferrer-Polonio ${ }^{\text {a, }}$, N.T. García-Quijano ${ }^{\text {, }}$ J.A. Mendoza-Roca ${ }^{\text {a }}$, A. Iborra-Clar ${ }^{\text {a }}$, L. PastorAlcañiz ${ }^{\mathrm{b}}$

${ }^{a}$ Instituto de Seguridad Industrial, Radiofísica y Medioambiental, Universitat Politècnica de València, Camino de Vera s/n, 46022 Valencia.

b Depuración de Aguas del Mediterráneo, Avda. Benjamin Franklin, 21, Parque Tecnológico, 46980 Paterna, Spain.

* Corresponding author at: Instituto de Seguridad Industrial, Radiofísica y Medioambiental Universitat Politècnica de València Camino de Vera s/n 46022 Valencia. Tel. +34 963877630 Fax +34963877639.

e-mail address: evferpo@posgrado.upv.es, evaferrerpol@gmail.com

\begin{abstract}
The biological treatment of hypersaline wastewaters with high COD and phenols concentration requires long hydraulic retention times and much energy for aeration. In this work aeration time reduction in the reaction phase was studied in two sequential batch reactors (SBR) treating fermentation brine from table olive processing wastewater. To study the influence of an anaerobic phase on the SBR performance (for COD and phenolic compound removal efficiencies), different anaerobic/aerobic reaction times were evaluated.
\end{abstract}


SBR-1 was operated with an anaerobic/aerobic hours ratio of $0 / 22,8 / 14$ and 14/8 and SBR-2 with a ratio of $22 / 0,14 / 8$ and $8 / 14$. Results showed that the maximum organic matter reduction was obtained under aerobic reaction conditions (ratio $0 / 22$ ) with a $82.3 \%$ and $77.9 \%$ of COD and total phenols removal, respectively. However, optimal conditions were considered to prevail for an anaerobic/aerobic ratio of $8 / 14$, since the reactors performances were similar with lower energy consumption. Thus, $82.3 \%$ and $79.5 \%$ of COD and $77.9 \%$ and $78.3 \%$ of total phenols were removed in SBR-1 and SBR-2, respectively.

Keywords: Biological wastewater treatment; SBR; Phenolic compounds; Hypersaline wastewater; Anaerobic/aerobic phases.

Nomenclature:

$\begin{array}{ll}\text { HRT } & \text { Hydraulic retention time (days) } \\ \text { T.Ph } & \text { Total phenols }\left(\mathrm{mg} \cdot \mathrm{L}^{-1}\right) \\ \mathrm{Cl}^{-} & \text {Chloride }\left(\mathrm{mg} \cdot \mathrm{L}^{-1}\right) \\ \mathrm{N}_{\mathrm{T}} & \text { Total nitrogen }\left(\mathrm{mg} \cdot \mathrm{L}^{-1}\right) \\ \mathrm{P}_{\mathrm{T}} & \text { Total phosphorus }\left(\mathrm{mg} \cdot \mathrm{L}^{-1}\right) \\ \mathrm{SS} & \text { FTOP suspended solids }\left(\mathrm{mg} \cdot \mathrm{L}^{-1}\right) \\ \mathrm{VSS} & \text { FTOP volatile suspended solids }\left(\mathrm{mg} \cdot \mathrm{L}^{-1}\right) \\ \mathrm{SS} & \text { Effluent suspended solids }\left(\mathrm{mg} \cdot \mathrm{L}^{-1}\right) \\ \mathrm{Q}_{\mathrm{ef}} & \text { Daily effluent volume draw from the } \mathrm{SBR}\left(\mathrm{L} \cdot \mathrm{d}^{-1}\right) \\ \Delta \mathrm{t}_{\mathrm{ij}} & \text { Time between two measures }(\text { day }) \\ \text { MLSS } & \text { Mixed liquor suspended solids }\left(\mathrm{mg} \cdot \mathrm{L}^{-1}\right)\end{array}$




\begin{tabular}{|c|c|}
\hline MLVSS & Mixed liquor volatile suspended solids $\left(\mathrm{mg} \cdot \mathrm{L}^{-1}\right)$ \\
\hline DO & Dissolved oxygen $\left(\mathrm{mg} \cdot \mathrm{L}^{-1}\right)$ \\
\hline time $_{\mathrm{DO}}$ & Time (min) in a cycle in that DO concentrations were higher than $0.1 \mathrm{mg} \cdot \mathrm{L}^{-1}$ \\
\hline time $_{\text {air }}$ & Time (min) in a cycle in that compressor supplied air into the reactor \\
\hline $\mathrm{F} / \mathrm{M}$ & Food-to-microorganism ratio $\left(\mathrm{kg} \mathrm{COD} \cdot \mathrm{kg} \mathrm{MLVSS}{ }^{-1} \cdot \mathrm{d}^{-1}\right)$ \\
\hline$\Delta \mathrm{X}$ & Sludge production $\left(\mathrm{mg}\right.$ MLSS $\left.\cdot \mathrm{L}^{-1} \cdot \mathrm{d}^{-1}\right)$ \\
\hline OUR & Oxygen uptake rate in mixed liquor $\left(\mathrm{mg} \mathrm{O}_{2} \cdot \mathrm{L}^{-1} \cdot \mathrm{d}^{-1}\right)$ \\
\hline SOUR & Specific OUR $\left(\mathrm{mg} \mathrm{O}_{2} \cdot \mathrm{mg} \mathrm{MLVSS}^{-1} \cdot \mathrm{d}^{-1}\right)$ \\
\hline $\mathrm{Y}_{\mathrm{H}}$ & heterotrophic biomass yield coefficient ( $\mathrm{g}$ cell COD·g soluble COD) \\
\hline $\mathrm{C}_{\mathrm{O} 2}$ & DO concentration in the mixed liquor $\left(\mathrm{mg} \mathrm{O}_{2} \cdot \mathrm{L}^{-1}\right)$ \\
\hline $\mathrm{COD}_{\mathrm{Ac}}$ & Chemical oxygen demand for the sodium acetate $\left(\mathrm{mg} \mathrm{O}_{2} \cdot \mathrm{L}^{-1}\right)$ \\
\hline $\mathrm{CO}_{\mathrm{Ac}}$ & Consumed oxygen in sodium acetate biodegradation $\left(\mathrm{mg} \mathrm{O}_{2} \cdot \mathrm{L}^{-1}\right)$ \\
\hline
\end{tabular}

\section{INTRODUCTION}

Hypersaline effluents are generated in very large amounts by some types of industrial activities, such as tanneries, petroleum and food processing industries [1]. In addition to high conductivity, these wastewaters often include high concentrations of organic matter and toxic compounds. Therefore an effective treatment, before their discharge into the environment, is necessary.

Hypersaline effluents were commonly transferred to evaporation ponds in order to concentrate salt and organic matter. However, there is a decrease in the use of this technique due to the more restrictive environmental regulations. Physico-chemical techniques focusing on organic compounds removal like electro-coagulation [2], ozonation [3] and Fenton's 
reagent [4] have been proposed by some authors for their management. However, these are very expensive and are not usually appropriate for large volumes of wastewater [5]. Biological wastewater treatment is an efficient alternative. This technique offers low associated costs and it is more environmentally friendly than physico-chemical treatments. However, salinity makes biological treatment difficult [6-8]. In municipal wastewater treatment plants with non salt adapted sewage sludge, salt concentrations above $1-2 \%$ can lead to loss of activity of cells and to a decrease of settlement capacity and bioflocculation [9]. Thus, salt adapted sludge is required to treat hypersaline effluents.

Fermentation brine from table olive processing (FTOP) is one of these hypersaline industrial effluents. The biological treatment of FTOP is very difficult because high concentrations of phenolic compounds are combined with the high salinity. The bactericidal effect of phenolic compounds can produce biomass inhibition, what has been reported by several authors $[10,11]$. Although a direct biological treatment of FTOP has not yet been reported in the literature until now, a recent study carried out by our research group showed the successful start-up of a biological reactor for FTOP treatment [12]. FTOP is an acidic industrial effluent ( $\mathrm{pH}$ around 4) with high conductivity (above $60 \mathrm{mS} \cdot \mathrm{cm}^{-1}$ ). The COD and total phenolic compounds concentration depend on olive processing method, cultivar and olive maturation [13]. According to our data from thirty-six FTOP samples, the COD ranges between 6 and 20 $\mathrm{g} \cdot \mathrm{L}^{-1}$ and the total phenols concentration varies between 0.5 and $1.7 \mathrm{~g} \cdot \mathrm{L}^{-1}$. The main phenolic compounds in FTOP are hydroxytyrosol (HTY) and tyrosol (TY), with HTY concentrations being predominant in FTOP wastewater [14]. Brenes et al. [15] and Fendri et al. [16] reported that, during debittering step of olive processing, HTY and TY are the hydrolysis products of oleuropein and ligstroside, respectively.

For start-up of an SBR process and further operation it was checked that high hydraulic retention time of 40 days and a long duration of aerobic phases (1/21 hours of 
anaerobic/aerobic for reaction) were required [12]. Thus, the next and crucial step to achieve a successful full-scale application is minimizing the energy consumption, i.e. aeration time. Aeration process may cause around $40-60 \%$ of the energy consumption in wastewater treatment plants $[17,18]$ frequently providing more oxygen than required $[19,20]$. On the other hand, the integrated anaerobic-aerobic SBR system is a suitable technology for treatment of high concentrations of organic matter in industrial wastewater treatment, e.g. for color and organic compounds removal from textile wastewater [21,22] and for polycyclic aromatic hydrocarbons removal [23,24]. Thus, a combination of aerobic and anaerobic degradation in a single reactor has been reported by several researchers. The aim of alternating aerobic and anaerobic phases is to enhance the biodegradation of organic matter that is refractory when only aerobic conditions are applied. This kind of integrated bioreactor can be operated with, or without, physical separation of anaerobic and aerobic zones: e.g Yang et al. [25] used a bioreactor with physical separation to treat landfill leachate. Tartakovsky et al. [26] studied trichloroethylene biodegradation in a single stage coupled anaerobic-aerobic granular biofilm reactor.

The above mentioned lack of literature about the direct biological treatment of FTOP and the shortage of studies on the biological treatment of wastewaters with salinities above $60 \mathrm{mS} / \mathrm{cm}$ makes it worth evaluating the effect of alternating anaerobic and aerobic phases in the SBR operation on its performance and on the respirometric parameters of such acclimated biomass to salinity. Thus, the aim of this work was to study the effects of reducing aeration time during SBR treatment of FTOP wastewater in view of reducing the energy consumption and enhancing the organic matter degradation. For this purpose, two identically SBRs were operated performing three experiments. In SBR-1 aeration time was progressively decreased: in the first experiment aeration was $22 \mathrm{~h}$ per cycle, in the second one $14 \mathrm{~h}$ per cycle and in the 
third experiment it was $8 \mathrm{~h}$ per cycle. Unlike SBR-1, in SBR-2 aeration time was progressively increased with aeration times per cycle of 0,8 and $14 \mathrm{~h}$ in the experiments.

\section{MATERIALS AND METHODS}

\subsection{Wastewater characterization}

Brine was provided by a table olive packaging industry located in Comunidad Valenciana (Spain). Four FTOP samples were used in the experimental time, named FTOP-1, FTOP-2, FTOP-3 and FTOP-4. To eliminate the flesh and stone olive remains, FTOP samples were filtered in a $60 \mu \mathrm{m}$ sieve. Samples were stored at $4^{\circ} \mathrm{C}$ until use.

Table 1 presents the main characteristics of the FTOP samples used in the experiments.

Table 1. FTOP samples characterisation

\begin{tabular}{|l|c|c|c|c|}
\cline { 2 - 5 } \multicolumn{1}{c|}{} & FTOP-1 & FTOP-2 & FTOP-3 & FTOP-4 \\
\hline Operational days & $1-6$ & $7-62$ & $63-90$ & $91-105$ \\
\hline $\mathbf{p H}$ & $4.3 \pm 0.1$ & $4.2 \pm 0.1$ & $4.2 \pm 0.1$ & $4.3 \pm 0.1$ \\
Cond $\left(\mathbf{m S} \cdot \mathbf{c m}^{-\mathbf{1}}\right)$ & $66.1 \pm 0.3$ & $67.4 \pm 0.3$ & $72.7 \pm 0.5$ & $72.5 \pm 0.7$ \\
$\mathbf{C O D}\left(\mathbf{g} \cdot \mathbf{L}^{-\mathbf{1}}\right)$ & $6.76 \pm 0.09$ & $12.19 \pm 0.11$ & $12.01 \pm 0.03$ & $15.27 \pm 0.21$ \\
$\mathbf{C l}\left(\mathbf{g} \cdot \mathbf{L}^{-\mathbf{1}}\right)$ & $28.03 \pm 0.23$ & $27.60 \pm 0.31$ & $32.99 \pm 0.15$ & $32.81 \pm 0.12$ \\
$\mathbf{N}_{\mathbf{T}}\left(\mathbf{m g} \cdot \mathbf{L}^{-\mathbf{1}}\right)$ & $104 \pm 3$ & $190 \pm 6$ & $201 \pm 12$ & $254 \pm 7$ \\
$\mathbf{P}_{\mathbf{T}}\left(\mathbf{m g} \cdot \mathbf{L}^{-\mathbf{1}}\right)$ & $18 \pm 1$ & $39 \pm 1$ & $53 \pm 3$ & $54 \pm 6$ \\
$\mathbf{T . P h}\left(\mathbf{m g ~ T Y} \cdot \mathbf{L}^{-\mathbf{1}}\right)$ & $594 \pm 25$ & $1345 \pm 45$ & $1330 \pm 26$ & $1670 \pm 31$ \\
$\mathbf{S S}\left(\mathbf{m g} \cdot \mathbf{L}^{-\mathbf{1}}\right)$ & $1840 \pm 62$ & $3086 \pm 85$ & $3564 \pm 46$ & $2256 \pm 31$ \\
$\mathbf{V S S}\left(\mathbf{m g} \cdot \mathbf{L}^{-\mathbf{1}}\right)$ & $1230 \pm 23$ & $2378 \pm 52$ & $2512 \pm 43$ & $1310 \pm 41$ \\
\hline
\end{tabular}

It can be observed that the FTOP is an acidic wastewater. Thus, the $\mathrm{pH}$ average value for the four samples was $4.3 \pm 0.1$. The conductivity was very high $\left(69.7 \pm 3.4 \mathrm{mS} \cdot \mathrm{cm}^{-1}\right)$ due to the high salt concentrations (around $8 \% \mathrm{NaCl}$ ) in fermentation brines [27]. However, considerable differences between samples 1 and 4 were observed for the other parameters 
(Table 1). For example the mean values of the COD and total phenols were $11.56 \pm 3.5 \mathrm{~g} \cdot \mathrm{L}^{-1}$ and $1235 \pm 455 \mathrm{mg} \cdot \mathrm{L}^{-1}$, respectively. These parameters depend on olive cultivar $[13,28]$ and maturation degree [29], as well as debittering and fermentation times [15]. The phenolic profile performed in the four FTOP samples showed that hydroxytyrosol (HTY) was the main phenolic compound and tyrosol (TY) was the second one. This has been detailed in section 3.2. These results agree with those reported in other research works $[15,16]$.

Due to the measured $\mathrm{N}_{\mathrm{T}}$ and $\mathrm{P}_{\mathrm{T}}$ concentrations, nutrients were added with the aim of maintaining the ratio of COD:N:P, in the feed FTOP, at 250:5:1 throughout the biological treatment. Urea $\left(\mathrm{NH}_{2} \mathrm{CONH}_{2}\right)$ and dipotassium phosphate $\left(\mathrm{K}_{2} \mathrm{HPO}_{4}\right)$ were employed as a nitrogen and phosphorous source, respectively.

\subsection{Reactors and experimental methodology}

Experiments were carried out in two identical cylindrical sequencing batch reactors (SBR-1 and SBR-2), which operated with previously adapted biomass to FTOP [12]. The reactors had a diameter of $10 \mathrm{~cm}$ and a height of $30 \mathrm{~cm}$. Mechanical components and a scheme of the SBRs plant can be found in a previous work [12]. Table 2 shows the operating conditions and the cycle phases in both reactors over the experimental time. 
Table 2. SBRs operation characteristics.

\begin{tabular}{lc}
\hline & Operating characteristics \\
\hline Reaction volume & $6 \mathrm{~L}$ \\
Feed/draw volume & $360 \mathrm{~mL} \cdot \mathrm{d}^{-1}$ \\
Hydraulic retention time & $16.6 \mathrm{days}$ \\
Daily number of cycles & 1 \\
Operation days & 105 \\
\hline \multicolumn{2}{l}{ Cycle characteristics } \\
\hline Phase & Time \\
\hline Filling & $2 \mathrm{~min}$ \\
Reaction & $22 \mathrm{~h}$ \\
Sedimentation & $1.5 \mathrm{~h}$ \\
Draw & $2 \mathrm{~min}$ \\
Idle & $26 \mathrm{~min}$ \\
\hline
\end{tabular}

The experiments were divided into three operational steps with different anaerobic/aerobic phase duration for each reactor. Anaerobic phases were performed under stirring conditions without aeration. Aerobic phases were maintained with stirring and aeration was controlled by an automated program. The duration of the aerobic phases was defined by the time air. Air flow was provided by a compressor $\left(9 \mathrm{~L} \cdot \mathrm{min}^{-1}\right)$ connected to a porous diffuser located on the bottom of the reactors. The performed operational steps were the following:

- Step-1 (38 days); the time air were $22 \mathrm{~h}$ in SBR-1 and $0 \mathrm{~h}$ in SBR-2.

- Step-2 (36 days); the time air $_{\text {were }} 14 \mathrm{~h}$ in SBR-1 and $8 \mathrm{~h}$ in SBR-2.

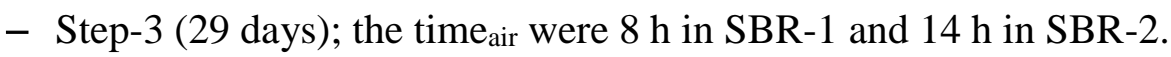

In the reaction, anaerobic phase always preceded aerobic phase.

\subsection{Analytical methods.}


Parameters measured in the FTOP wastewater were: $\mathrm{pH}$, conductivity, soluble COD (filtered to $0.45 \mu \mathrm{m}$ ), total phenols (T.Ph), phenolic profile, chloride $\left(\mathrm{Cl}^{-}\right)$, total nitrogen $\left(\mathrm{N}_{\mathrm{T}}\right)$, total phosphorus $\left(\mathrm{P}_{\mathrm{T}}\right)$, suspended solids (SS) and volatile suspended solids (VSS).

The effluents from SBRs were analyzed measuring $\mathrm{pH}$, conductivity, soluble COD and total phenols twice a week. Effluent suspended solids $\left(\mathrm{SS}_{\mathrm{ef}}\right), \mathrm{N}_{\mathrm{T}}$ and $\mathrm{P}_{\mathrm{T}}$ concentrations were controlled once a week. The phenolic profile was obtained at the beginning and at the end of the three experimental steps carried out.

The mixed liquor (ML) was controlled twice a week and the measured parameters were the following: temperature, suspended solids (MLSS) and volatile suspended solids (MLVSS). The dissolved oxygen (DO) was measured continuously and it was maintained below 2.5 $\mathrm{mg} \cdot \mathrm{L}^{-1}$; therefore aeration was automatically stopped when the DO exceeded this concentration. These values were recorded in a data acquisition system. The time Do was the time in which the oximeter registered an oxygen concentration above $0.1 \mathrm{mg} \cdot \mathrm{L}^{-1}$ in the mixed liquor (aerobic conditions). Another related parameter was the time ${ }_{a i r}$, defined as the time for which the system supplied air into the reactor. Respirometric measurements of the ML were also carried out. Thus, the oxygen uptake rate (OUR), specific oxygen uptake rate (SOUR) and the coefficient of performance of heterotrophic growth on chemical oxygen demand $\left(\mathrm{Y}_{\mathrm{H}}\right)$ were measured at the end of the three experiments.

The $\mathrm{pH}$ was determined with a $\mathrm{pH}-$ Meter GLP $21+$ and the conductivity was measured with an EC-Meter GLP 31+, both from Crison. The DO was measured by an oximeter from Crison. The $\mathrm{SS}_{\mathrm{ef}}, \mathrm{SS}, \mathrm{VSS}, \mathrm{MLSS}$ and MLVSS were obtained according to APHA, 2005 [30]. Reactive kits and a Spectrophotometer DR600, both from Hach Lange, were used to determined $\mathrm{Cl}^{-}, \mathrm{N}_{\mathrm{T}}, \mathrm{P}_{\mathrm{T}}$ and soluble COD (filtrate to $0.45 \mu \mathrm{m}$ ), after the appropriate dilutions to avoid interferences. 
In addition, the MLVSS/MLSS relationship and food-to-microorganism ratio (F/M) were calculated. The F/M was calculated by Eq.(1) [31]:

$$
\mathrm{F} / \mathrm{M}=\frac{\mathrm{COD}_{0} \cdot \mathrm{Q}}{\mathrm{V}_{\mathrm{R}} \cdot \mathrm{MLVSS}}
$$

where $\mathrm{COD}_{0}$ was the influent $\mathrm{COD}$ concentration $\left(\mathrm{mg} \cdot \mathrm{L}^{-1}\right), \mathrm{Q}$ was the daily wastewater

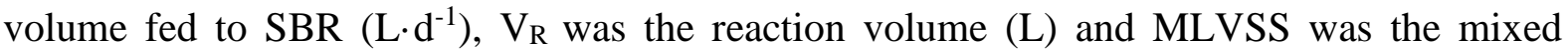
liquor volatile suspended solids $\left(\mathrm{mg} \cdot \mathrm{L}^{-1}\right)$.

The sludge production $(\Delta \mathrm{X})$, considering both the non-biodegradable suspended solids of the FTOP and the bacterial growth, was obtained by equation 2 . This equation takes into account two terms: the first term is the MLSS concentration difference in SBR between two consecutive measurements (days $\mathrm{i}$ and $\mathrm{j}$ ), which also included the non-biodegradable SS of the FTOP wastewater. The second term corresponds to the biomass lost in the effluent:

$$
\Delta \mathrm{X}=\frac{1}{\mathrm{~V}_{\mathrm{R}}} \cdot\left(\frac{\left(\mathrm{MLSS}_{\mathrm{j}}-\mathrm{MLSS}_{\mathrm{i}}\right) \cdot \mathrm{V}_{\mathrm{R}}}{\Delta \mathrm{t}_{\mathrm{ij}}}+\mathrm{SS}_{\mathrm{ef}} \cdot \mathrm{Q}_{\mathrm{ef}}\right)
$$

where $Q_{e f}$ is the daily effluent volume drawn from the SBR $\left(\mathrm{L}^{-} \mathrm{d}^{-1}\right)$ and $\Delta \mathrm{t}_{\mathrm{ij}}$ is the time between two measures (day). No sludge was withdrawn during the days considered for the calculation. Biomass growth is included in the sludge production. As the VSS/SS ratio in the FTOP samples remained practically constant, it can be assumed that variations in the sludge production during the experiments were generated by changes in biomass growth.

\section{Total Phenols and phenolic profile}

The total phenols were measured according to the Folin-Ciocalteu method adapted to Singleton et al. [32]. Sodium carbonate $(20 \%$ w/v) from Panreac, Folin \& Ciocalteu's reagent 
and Tyrosol analytical standard (both from Sigma Aldrich) were used. Results were expressed as equivalent of tyrosol $\left(\mathrm{mg} \mathrm{TY} \cdot \mathrm{L}^{-1}\right)$.

The phenolic profile was obtained by High-performance liquid chromatography (HPLC). Phenols were extracted from the FTOP samples according to El-Abbassi et al. [33] method, before HPLC analysis. Jasco HPLC system equipped with a MD-2018 Photodiode Array detector with a Phenomenex Kinetex 5u Biphenyl 100A column (4.6 x 250 mm, $5 \mu \mathrm{m})$ were used. The chromatographic method employed was the following: flow rate of $1.5 \mathrm{~mL} \cdot \mathrm{min}^{-1}$; injection volume of $10 \mu \mathrm{L}$; solvent system were phase A (1\% acetic acid in water) and phase B (1\% acetic acid in methanol); gradient conditions: the elution started at 5\% of $\mathrm{B}$ and remained constant for $1 \mathrm{~min}$, it linearly increased up to $80 \%$ of $\mathrm{B}$ in $25 \mathrm{~min}$ and returned to $5 \%$ of $\mathrm{B}$ in 2 min.

\section{Respirometric techniques}

The OUR, SOUR and $\mathrm{Y}_{\mathrm{H}}$ parameters were measured by a respirometer BM-Advance from Surcis. OUR is the oxygen uptake rate in the mixed liquor and SOUR is the specific OUR. $\mathrm{Y}_{\mathrm{H}}$ is the heterotrophic biomass yield coefficient. This equipment includes the following units: glass vessel, oximeter, $\mathrm{pH}$-meter, mechanical stirrer and air diffuser $\left(1.2 \mathrm{~L} \cdot \mathrm{min}^{-1}\right)$. Additionally, the temperature in the vessel was maintained by an external heating/cooling system. Respirometric analysis was performed with one litre of ML, collected at the end of the reaction phase. The set temperature was the operating temperature of the SBR. Once temperature was adjusted the aeration was switched on. Air supply was maintained until endogenous conditions for the biomass were achieved. From these conditions, two analyses were carried out: static analysis (without oxygen addition) to determine OUR/SOUR and 
dynamic analysis (providing oxygen) to obtain $\mathrm{Y}_{\mathrm{H}}$ with sodium acetate addition (readily biodegradable substrate).

In static respirometric analysis aeration was stopped, while the other equipment parts remained connected (stirrer, oximeter...). DO was monitored. Under these conditions, the mass balance for the DO is the following [34,35]:

$$
\frac{\mathrm{dC}_{\mathrm{O}_{2}}}{\mathrm{dt}}=-\mathrm{OUR}
$$

where $\mathrm{C}_{2}$ was the DO concentration in the mixed liquor. Thus, OUR $\left(\mathrm{mg} \mathrm{O} \mathrm{O}_{2} \cdot \mathrm{L}^{-1} \cdot \mathrm{h}^{-1}\right.$ ) was calculated from the slope of the plot of dissolved oxygen concentration versus time. SOUR $\left(\mathrm{mg} \mathrm{O}_{2} \cdot \mathrm{g}^{-1} \cdot \mathrm{h}^{-1}\right.$ ) was obtained from Eq.(4):

$$
\text { SOUR }=\frac{\text { OUR }}{\text { MLVSS }}
$$

In dynamic respirometric analyses, heterotrophic biomass was evaluated. Aeration did not stop and allyl thiourea as an inhibitor of ammonium oxidizing bacteria was added in a ratio of $2 \mathrm{mg} \mathrm{ATU/g} \mathrm{MLVSS} \mathrm{at} \mathrm{least} 20$ minutes before the respirometric test. A volume of $50 \mathrm{~mL}$ of sodium acetate $\left(\mathrm{C}_{2} \mathrm{H}_{3} \mathrm{NaO}_{2}\right)$, with a $\mathrm{COD}_{\mathrm{Ac}}$ around $300 \mathrm{mg} \mathrm{O} \cdot \mathrm{L}^{-1}$, was added $(400 \mathrm{mg}$ of $\mathrm{C}_{2} \mathrm{H}_{3} \mathrm{NaO}_{2}$ for each $1000 \mathrm{~mL}$ of osmotic water) and the DO was monitored. At the beginning, the DO concentration decreased to a minimum value because the microorganisms consumed oxygen to metabolize sodium acetate. After that, the DO concentration increased up to the initial value, which implies total substrate oxidation [34,36]. Surcis software provided the consumed oxygen in this process, $\mathrm{CO}_{\mathrm{Ac}}\left(\mathrm{mg} \mathrm{O}_{2} \cdot \mathrm{L}^{-1}\right)$, which is related to the COD consumed for biomass respiration. $\mathrm{Y}_{\mathrm{H}}\left(\mathrm{g}\right.$ cell $\mathrm{COD} \cdot \mathrm{g}^{-1}$ soluble $\left.\mathrm{COD}\right)$, for the sodium acetate oxidation, was obtained by Eq.(5): 


$$
\mathrm{Y}_{\mathrm{H}}=1-\frac{\mathrm{CO}_{\mathrm{Ac}}}{\mathrm{COD}_{\mathrm{Ac}}}
$$

where $\mathrm{COD}_{\mathrm{Ac}}$ was the spectrophotometrically measured COD of the added sodium acetate.

\section{RESULTS AND DISCUSSION}

\subsection{SBR-1}

Throughout the experimental period, the temperature was $24.2 \pm 1.9^{\circ} \mathrm{C}$ and the $\mathrm{pH}$ was $8.4 \pm$ 0.2 in SBR-1. This $\mathrm{pH}$ value was due to the biological oxidation of the organic acids in the FTOP samples (mainly lactic, malic, formic and acetic acid) [37]. Conductivity values in the SBR depended on the feed FTOP wastewater. Thus, in the first 63 days conductivity was 67.5 $\pm 1.4 \mathrm{mS} \cdot \mathrm{cm}^{-1}$, meanwhile this value increased progressively when FTOP-3 was fed. Finally, from the $83^{\text {rd }}$ day onwards the conductivity remained at $75.1 \pm 1.5 \mathrm{mS} \cdot \mathrm{cm}^{-1}$.

\subsubsection{Sludge production}

Figure 1 shows the MLSS, MLVSS, MLVSS/MLSS ratio and sludge production, for 105 days of SBR-1 operation. 


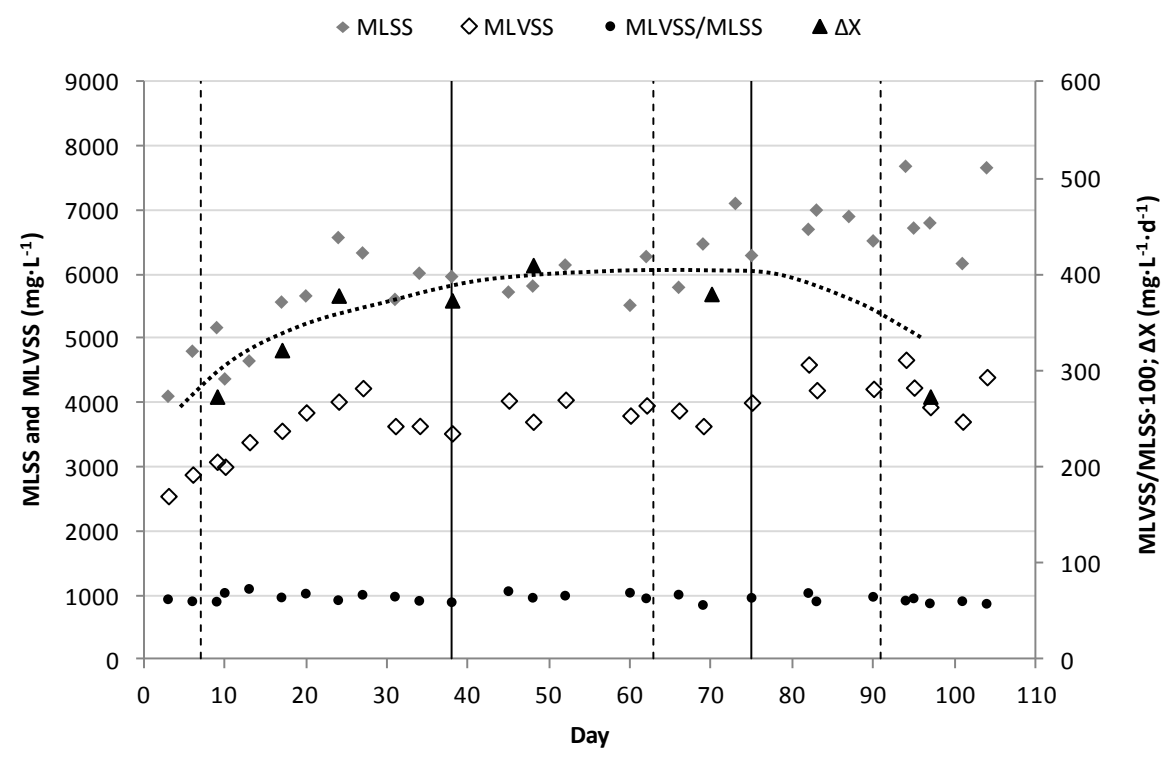

Figure 1. SBR-1 ML: MLSS, MLVSS, MLVSS/MLSS and $\Delta X$.

Vertical lines: [-] separate the experimental steps; [- - ] separate the FTOP feeding. Curved line $[\cdots \cdots]$ : trend of sludge production $(\Delta \mathrm{X})$.

The initial increase in organic load, due to the fact that the COD of FTOP-2 was higher than FTOP-1, implied that the biomass growth increased and the $\Delta \mathrm{X}$ varied from the 273 to 373 $\mathrm{mg} \cdot \mathrm{L}^{-1} \cdot \mathrm{d}^{-1}$ throughout Step-1. No sludge withdrawal was carried out until a concentration of around $4000 \mathrm{mg} \cdot \mathrm{L}^{-1}$ of the MLVSS was achieved $\left(27^{\text {th }}\right.$ day). From this moment on, a periodic sludge withdrawal was performed to maintain the MLSS concentrations between 5500 y 6500 $\mathrm{mg} \cdot \mathrm{L}^{-1}$ and the MLVSS concentrations between 3500 y $4500 \mathrm{mg} \cdot \mathrm{L}^{-1}$. The MLVSS/MLSS ratio was $0.64 \pm 0.04$ throughout the three experimental steps. In Step-2, when the time air was reduced to $8 \mathrm{~h}$, the biomass growth remained constant since the $\Delta \mathrm{X}$ registered in this period was $388 \pm 20 \mathrm{mg} \cdot \mathrm{L}^{-1} \cdot \mathrm{d}^{-1}$. However, in Step-3 the biomass growth decreased $(\Delta \mathrm{X}$ diminished until $273 \mathrm{mg} \cdot \mathrm{L}^{-1} \cdot \mathrm{d}^{-1}$ in the $97^{\text {th }}$ day), due to the drastic aeration reduction. This phenomenon is shown in many studies that reported the oxic-settling-anoxic (OSA) process [38-40]. Reduction of the biomass growth in the OSA activated sludge process could be due to the sludge fasting/feasting conditions. In the anaerobic reaction time there are insufficient food 
conditions whereas in the oxic reaction time there are sufficient food conditions [41]. In the OSA process, the catabolism is promoted front of the anabolism by uncoupling the two reactions. Adenosine triphosphate (ATP) is synthesized when aerobic microorganisms oxidize the organic matter, which is captured serving as an energy source for growth. Under anaerobic conditions, neither oxygen nor nitrates are available as electron acceptors and the ATP production is not possible. Thus, the same microorganisms have to consume their stored ATP. When aerobic conditions are set again, the increase of the ATP reserves is enhanced against the synthesis of cell mass. Therefore, sludge reduction occurs [38].

\subsubsection{Removal of organic matter and phenolic compounds from FTOP}

Figure 2 shows the soluble COD and total phenols removal percentages, the F/M ratio, the time $_{\text {air }}$ and the time DO.

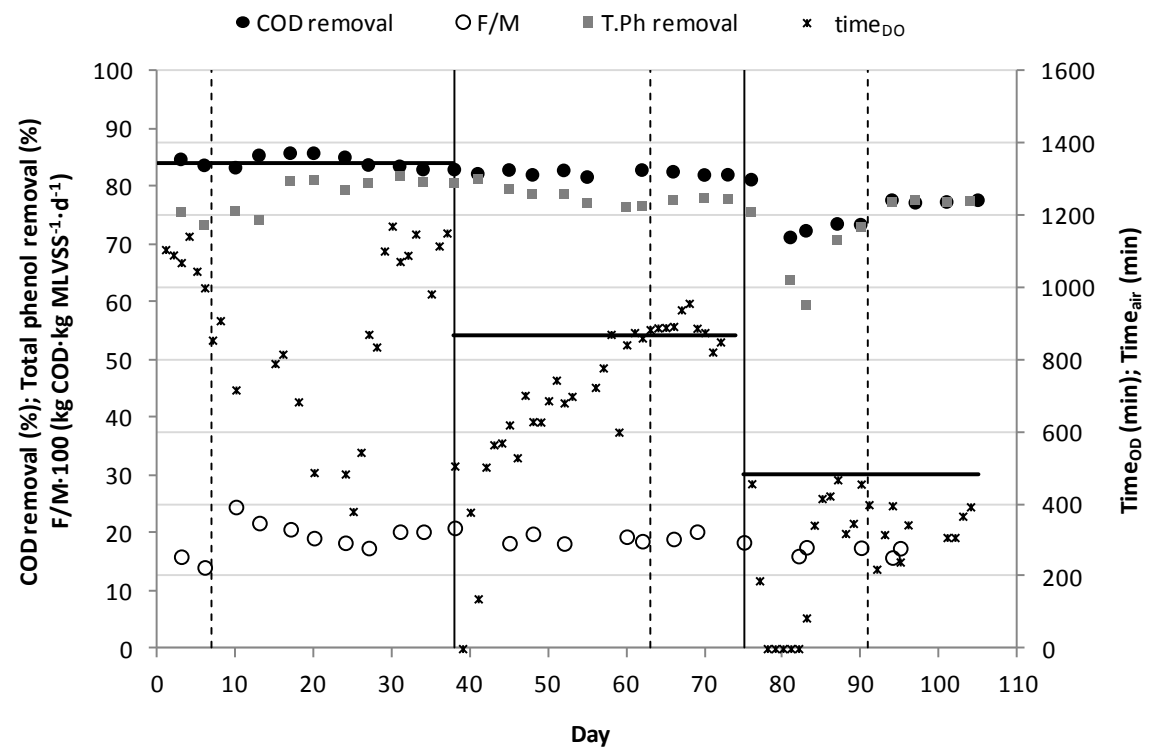

Figure 2. SBR-1 effluent: COD and Total phenols removal (\%) and Timedo. Vertical lines: [--] separate the experimental steps; [- - - ] separate the FTOP feeding. Horizontal lines: $[-]$ Timeair. 
When FTOP-2 was fed, the F/M ratio increased from 0.14 to $0.24 \mathrm{~kg} \mathrm{COD} \cdot \mathrm{kg} \mathrm{MLVSS}^{-1} \cdot \mathrm{d}^{-1}$ because this sample had higher COD than FTOP-1. This parameter decreased when the MLVSS increased in SBR-1 since both the flow rate and the COD of the feed remained constant. From the $31^{\text {st }}$ day on, the F/M ratio was maintained at $0.19 \pm 0.01 \mathrm{~kg} \mathrm{COD} \cdot \mathrm{kg}$ $\operatorname{MLVSS}^{-1} \cdot \mathrm{d}^{-1}$ because the MLVSS concentration was set between 3500 and $4500 \mathrm{mg} \cdot \mathrm{L}^{-1}$ by regulating the sludge withdrawals.

The reduction in time DO $_{\text {in }}$ the first days of Step-1 was due to the increase in the organic load. This enhanced biomass growth, which implied more DO consumption until the microorganisms reached the stationary phase. In these conditions, the DO concentration increases again, since the oxygen demand becomes smaller [42]. From the $25^{\text {th }}$ day the time $_{\mathrm{DO}}$ increased progressively. For the last 21 days the mean COD removal percentage was $84.2 \pm 1.1 \%$. The time air reduction from Step-1 to Step-2 hardly had any effect on the COD removal percentage, which was $82.3 \pm 0.4 \%$. However, in Step-3 this parameter diminished in the first days to $71.2 \%$ ( $81^{\text {st }}$ day) when the time air decreased to 8 hours. This phenomenon occurred because the DO was zero during the entire reaction time. Since these conditions were not the aimed ones, another compressor was added to supply more oxygen into the SBR-1 $\left(6 \mathrm{~L} \cdot \mathrm{min}^{-1}\right)$, achieving oxic conditions. As a consequence, from the $83^{\text {rd }}$ day on, both the DO and COD removal percentages increased. For the last 11 days, the COD removal percentage was $75.7 \pm 3.3 \%$.

The T.Ph removal percentage showed to be more sensitive to time ${ }_{\mathrm{DO}}$ variations than the COD removal percentage. For the last 11 days of each experimental step, when the DO was stabilized, the T.Ph removal percentage was $81.1 \pm 0.7 \%$ in Step- $1,77.9 \pm 0.7 \%$ in Step-2 and $77.4 \pm 0.2 \%$ in Step-3. Unlike other substances like dyes, whose biodegradation is enhanced by combining anaerobic and aerobic conditions [21,22], the degradation of the 
phenolic compounds in SBR-1 was not enhanced by applying this strategy. Figure 3 shows exemplarily the phenolic profile for FTOP-2 and the SBR effluent at the end of Step-2.
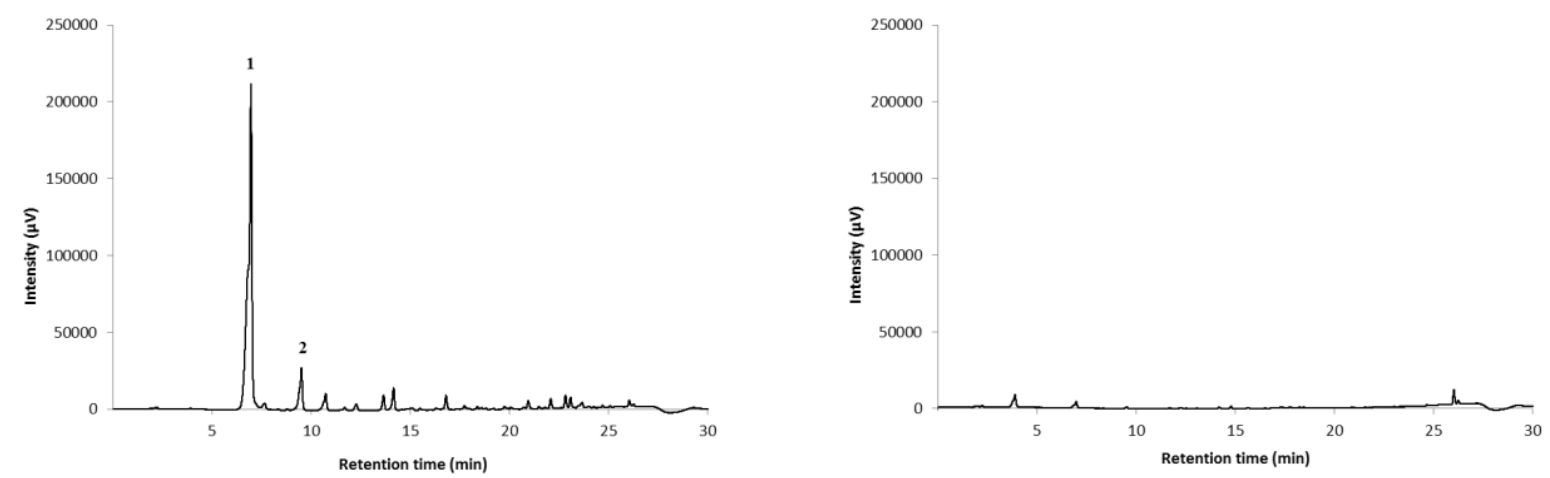

Figure 3. Phenolic profile to FTOP-2 and Step-2 in SBR-1. Peak identification: (1) Hydroxytyrosol; (2) Tyrosol.

It can be observed in the FTOP-2 chromatogram that HTY was the main phenolic compound followed by TY. This composition agrees with reports by other authors [14-16]. Chromatograms were similar for the other FTOP samples (not shown).

\subsection{SBR-2}

Throughout the whole experimental period in SBR-2, both temperature and conductivity changes achieved similar results as in SBR-1. However, the evolution of the $\mathrm{pH}$ value was different. In Step-1 the $\mathrm{pH}$ decreased from 8.2 to 7.2 , between the $1^{\text {st }}$ and the $38^{\text {th }}$ day. This occurred because the organic acids removal decreased under anoxic conditions (time $\mathrm{DO}=0$ ). Aerobic conditions in Step-2 progressively increased the $\mathrm{pH}$ values to 8.6 , in the $52^{\text {nd }}$ day. From this day on, the $\mathrm{pH}$ remained at $8.6 \pm 0.2$. 


\subsubsection{Sludge production}

Figure 4 shows the MLSS, MLVSS, MLVSS/MLSS ratio and sludge production.

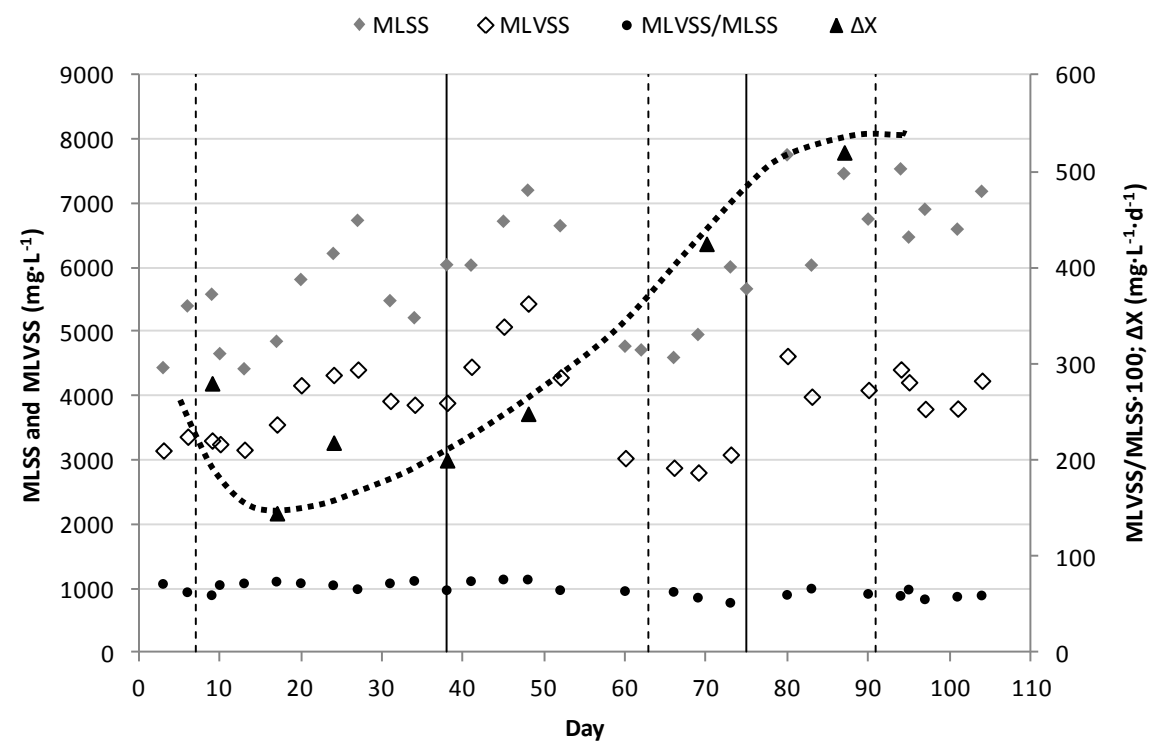

Figure 4. SBR-2 ML: MLSS, MLVSS, MLVSS/MLSS and $\Delta X$.

Vertical lines: [-] separate the experimental steps; [- - - ] separate the FTOP feeding.

Curved line $[\cdots \cdot]$ : trend of sludge production $(\Delta \mathrm{X})$.

In Step-1, when time $\mathrm{mg} \cdot \mathrm{L}^{-1} \cdot \mathrm{d}^{-1}$ in the $17^{\text {th }}$ day; therefore biomass growth also decreased. Similarly, an increase in the effluent turbidity was observed during this period. Both phenomena can be explained by cell death in this adverse condition. From this time on, no withdrawals were carried out. Due to the organic matter accumulation in the reactor, the MLVSS/MLSS ratio in the first 48 days was $0.70 \pm 0.05$. Additionally, $\Delta X$ increased slightly from the $20^{\text {th }}$ day, which does not necessarily mean an increase in the biomass growth, because the performance in SBR-2 decreased. This phenomenon can be explained because there was SS accumulation in SBR-2, due to the contribution of the FTOP suspended solids. As in SBR-1 in step 3, another compressor was necessary to increase the DO in Step-2. Although the time air was $8 \mathrm{~h}$, in the first days of operation the time 
the biomass growth increased quickly in Step-2 $\left(\Delta \mathrm{X}\right.$ increased to $425 \mathrm{mg} \cdot \mathrm{L}^{-1} \cdot \mathrm{d}^{-1}$ in the $70^{\text {th }}$ day). In Step-3, $\Delta X$ increased until $520 \mathrm{mg} \cdot \mathrm{L}^{-1} \cdot \mathrm{d}^{-1}$ on the $87^{\text {th }}$ day. The MLVSS/MLSS ratio in Step-2 and Step-3, decreased to $0.60 \pm 0.04$. This value was very similar to the one measured in SBR-1.

\subsubsection{Removal of organic matter and phenolic compounds from FTOP}

In Figure 5, the soluble COD and total phenols removal efficiencies, the F/M ratio, the time ${ }_{\text {air }}$ and time $\mathrm{DO}_{\mathrm{DO}}$ in SBR2 can be observed.

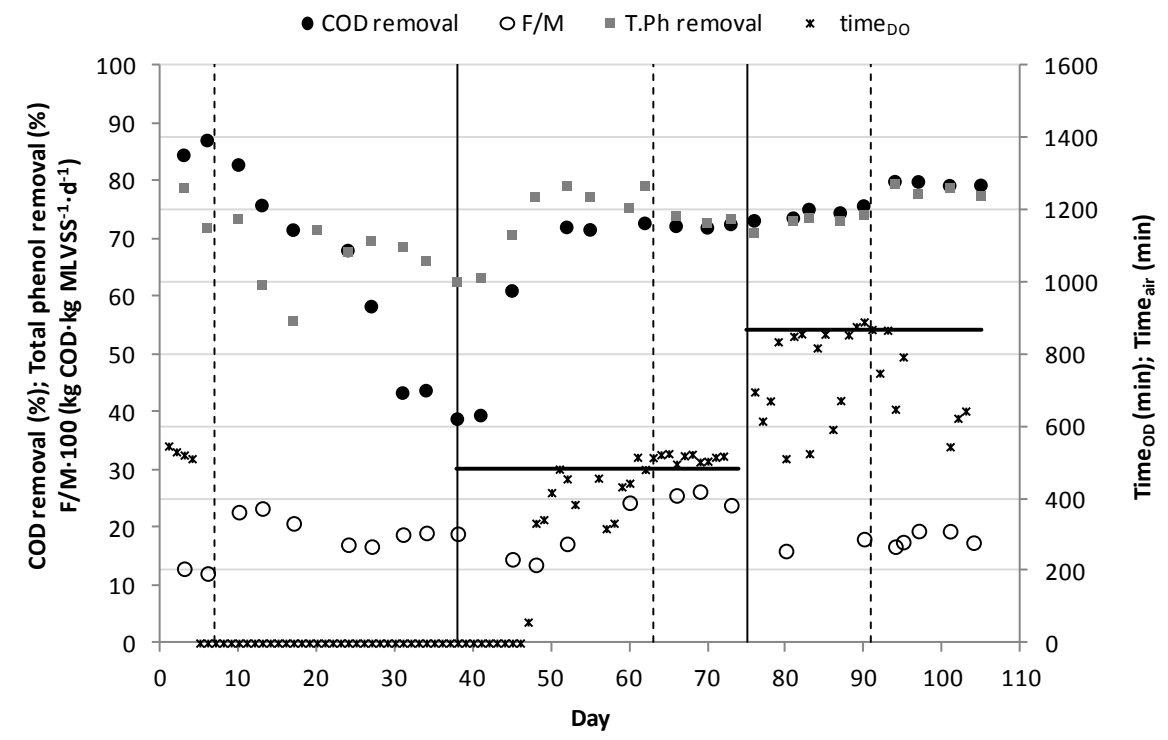

Figure 5. SBR-2 effluent: COD and Total phenols removal (\%) and TimeDO. Vertical lines: [--] separate the experimental steps; [- - - ] separate the FTOP feeding. Horizontal lines: $[-]$ Time air.

As it happened in SBR-1, FTOP-2 addition increased the F/M ratio from 0.12 to 0.23 $\mathrm{kg} \mathrm{COD} \cdot \mathrm{kg} \mathrm{MLVSS}{ }^{-1} \cdot \mathrm{d}^{-1}$. Nevertheless, it can be observed in figure 5 that from this moment on, fluctuations of this parameter were observed. This was due to the increase of the sludge production. As a consequence, the MLVSS concentrations also increased and these values 
exceeded the range of $3500-4500 \mathrm{mg} \cdot \mathrm{L}^{-1}$, until the withdrawn sludge volume was not properly raised.

In Step-1, a dramatic decrease in the COD removal percentage, on the $38^{\text {th }}$ day, can be observed; from $84.4 \%$ to $38.7 \%$. The same effect was observed in the T.Ph removal percentage in the first days. However, this parameter showed an improvement from the $18^{\text {th }}$ day (from $55.6 \%$ in $17^{\text {th }}$ day to $69.6 \%$ in $27^{\text {th }}$ day, as figure 5 shows), though TY and HTY were detected in SBR-2 effluent, as it can be seen in Figure 6.

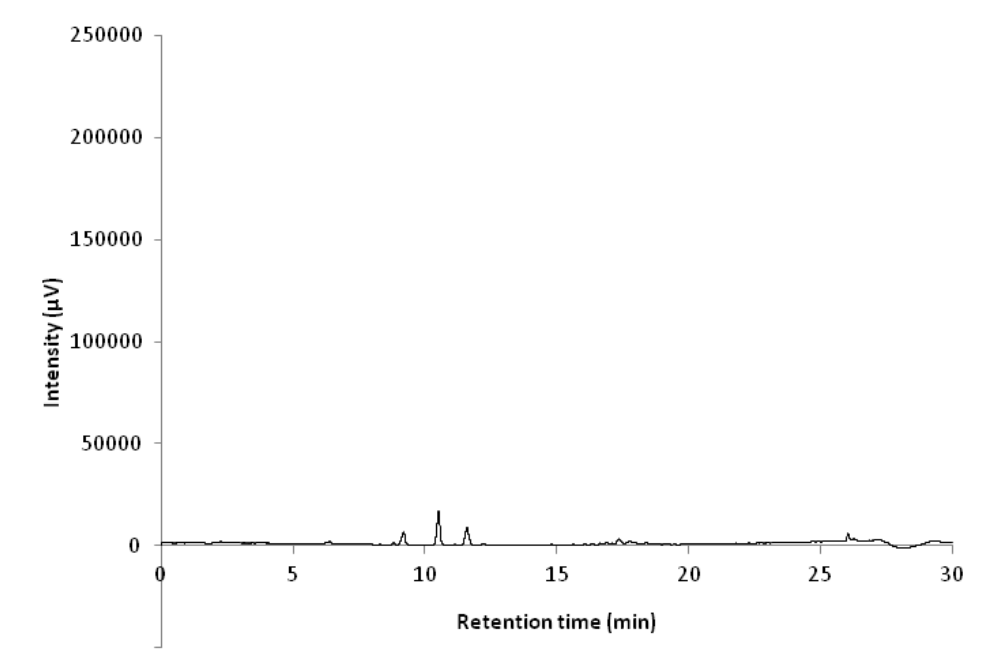

Figure 6. Phenolic profile to Step-2 in SBR-2.

This small increase in the T.Ph removal can be due to the enrichment in the biomass of facultative microorganism able to degrade phenols under strict anaerobic conditions [43], what did not occur in SBR-1. The anaerobic degradation of phenols mostly includes a carboxylation reaction that forms 4-hydroxybenzoate, followed by saturation of double bondages and ring cleavage [44]. Other mechanism that may have enhanced the removal of phenols in the SBR is the co-metabolism between phenols and rapidly biodegradable substrates like the organic acids contained in FTOP and those generated by anaerobic 
reactions. This phenomenon has been recently explained by the development of a cometabolism model for mixtures of phenol and m-cresol [45]. However, biomass was more effective in aerobic conditions, as it can be observed in the experiments with aerobic phase, in which the T.Ph removal was related to the time DO.

In Step-2 the COD and T.Ph removal percentages increased and from the $52^{\text {nd }}$ day on (when time $_{\text {DO }}$ was constant) they were maintained at $72.1 \pm 0.4 \%$ and $75.8 \pm 2.7 \%$, respectively. In the last 11 days of Step-3, the COD and T.Ph removal efficiency were $79.5 \pm 0.4 \%$ and 78.3 $\pm 1.0 \%$, respectively. This mean value of $\mathrm{T} . \mathrm{Ph}$. removal efficiency was very similar to that achieved at the beginning of the experiments. In contrast, the COD removal did not recover completely to the initial values.

\subsection{Respirometric characterization of the mixed liquors}

Table 3 shows the results obtained from the respirometric analysis, i.e. OUR, SOUR and $\mathrm{Y}_{\mathrm{H}}$. Other parameters such as the COD, T.Ph and $\Delta \mathrm{X}$ are also included.

In SBR-1, the SOUR measurements increased with decreasing aeration time. As it is known, the SOUR is related to microorganism activity; therefore its increase can be probably explained by the higher activity of the microorganisms under aerobic conditions, after being subjected to alternate anaerobic/aerobic conditions. In the same way, Wang et al. [46] reported that SOUR values increased when hydraulic retention time decreases. This also means that high SOUR values were associated to low reaction times for degrading organic matter. 
Table 3. Results of the respirometric analysis and their relation to the SBRs operating parameters.

\begin{tabular}{|c|c|c|c|c|c|c|}
\hline \multirow{2}{*}{ Parameter } & \multicolumn{3}{|c|}{ SBR-1 } & \multicolumn{3}{c|}{ SBR-2 } \\
\cline { 2 - 7 } & $\begin{array}{c}\text { Step-1 } \\
\mathbf{0}-\mathbf{3 8} \text { days }\end{array}$ & $\begin{array}{c}\text { Step-2 } \\
\mathbf{3 9 - 7 5} \text { days }\end{array}$ & $\begin{array}{c}\text { Step-3 } \\
\mathbf{7 6 - 1 0 5} \text { days }\end{array}$ & $\begin{array}{c}\text { Step-1 } \\
\mathbf{0 - 3 8} \text { days }\end{array}$ & $\begin{array}{c}\text { Step-2 } \\
\mathbf{3 9 - 7 5} \text { days }\end{array}$ & $\begin{array}{c}\text { Step-3 } \\
\mathbf{7 6 - 1 0 5} \text { days }\end{array}$ \\
\hline $\begin{array}{c}\text { OUR } \\
\left(\mathrm{mg} \mathrm{O}_{2} \cdot \mathrm{L}^{-1} \cdot \mathrm{h}^{-1}\right)\end{array}$ & 11.91 & 17.15 & 35.79 & - & 19.07 & 27.54 \\
\hline $\begin{array}{c}\text { SOUR } \\
\left(\mathrm{mg} \mathrm{O}_{2} \cdot \mathrm{g}^{-1} \cdot \mathrm{h}^{-1}\right)\end{array}$ & 3.27 & 4.71 & 8.13 & - & 6.79 & 6.5 \\
\hline $\begin{array}{c}\mathbf{Y}_{\mathbf{H}} \\
\left(\mathrm{g} \mathrm{cell} \mathrm{COD} \cdot \mathrm{g}^{-1} \mathrm{COD}\right)\end{array}$ & 0.22 & 0.26 & 0.21 & - & 0.50 & 0.27 \\
\hline $\begin{array}{c}\mathbf{\Delta X} \\
\left(\mathrm{mg} \cdot \mathrm{d}^{-1}\right)\end{array}$ & 2240 & 2280 & 1640 & - & 2550 & 2150 \\
\hline $\begin{array}{c}\mathbf{C O D} \\
\text { removal }(\%)\end{array}$ & 84.2 & 82.3 & 75.7 & 38.7 & 72.1 & 79.5 \\
\hline $\begin{array}{c}\mathbf{T} . P h \\
(\%)\end{array}$ & 81.1 & 77.9 & 77.4 & 69.6 & 75.8 & 78.3 \\
\hline
\end{tabular}

This argumentation also explains the behaviour in SBR-2, where the SOUR values diminished in Step-3 once the aeration time was increased. This increment was slight since the increase of the organic matter, due to higher influent COD provided by FTOP-4, entailed a lower time ${ }_{\text {DO }}$ increment. The SOUR measurement after Step-1 was not possible in SBR-2, because no endogenous conditions were reached after 8 hours of extended aeration.

Since the MLVSS concentration varied throughout the experimental steps, the SOUR parameter is better than the OUR to compare the oxygen uptake rate variations. The

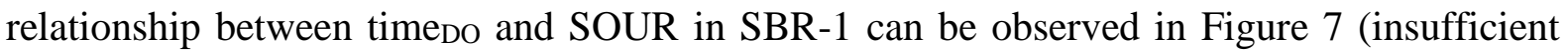
available SOUR values make no possible to evaluate this relationship in SBR-2). In this figure, SOUR values presented in Table 3 are plotted versus time DO $_{\text {. Represented time }}$ values were those reached in the last days of each experimental step (mean values and standard deviation). 


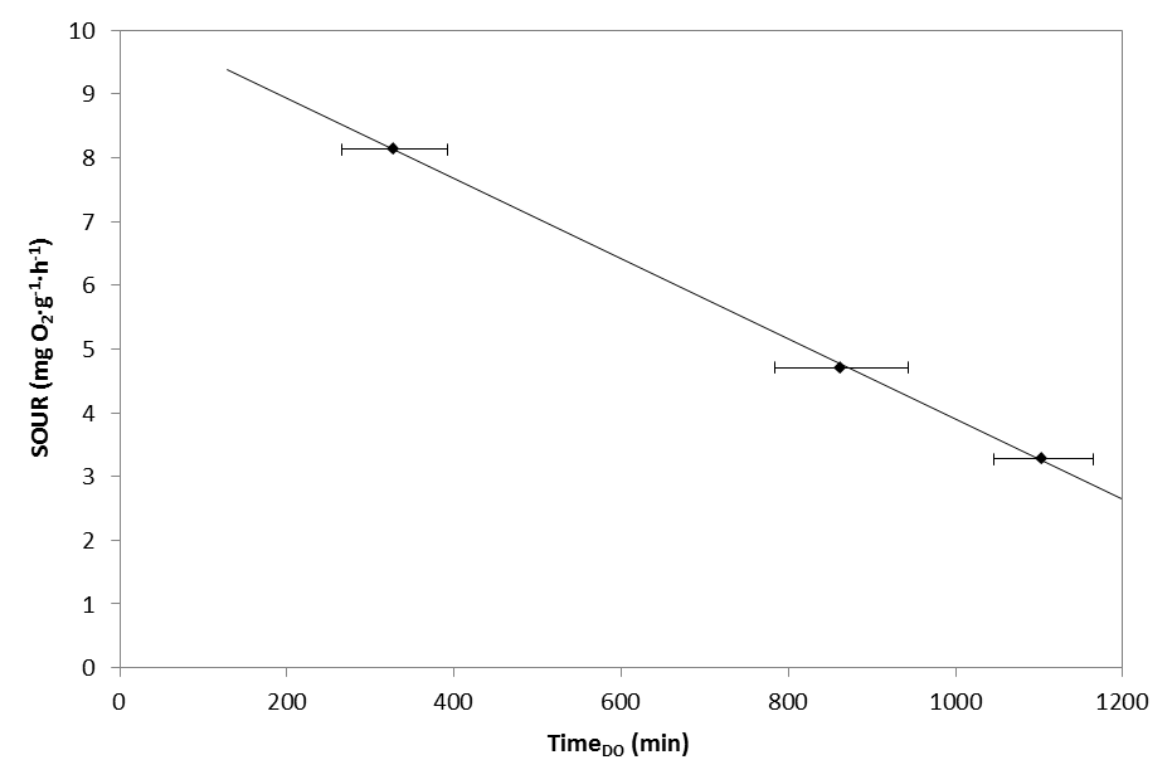

Figure 7. Relationship between timeno and SOUR in the SBR-1

A linear correlation was observed between both parameters according the following equation:

SBR $-1: \quad$ SOUR $=10.183-0.006 \cdot$ time $_{\text {DO }}$

where $\mathrm{R}^{2}$ value was 1.000 .

As expected, $\mathrm{Y}_{\mathrm{H}}$ was related to the $\Delta \mathrm{X}$ and consequently with the biomass growth, since the biomass growth is a parameter that indicates the apparent microorganisms growth. The $\mathrm{Y}_{\mathrm{H}}$ for the activated sludge treating domestic wastewaters is around 0.65 If it is compared with the values presented in table 3, it can be observed that $\mathrm{Y}_{\mathrm{H}}$ for domestic wastewaters was higher than $\mathrm{Y}_{\mathrm{H}}$ for the FTOP samples in all experiments performed. The osmotic pressure caused by the high salinity implies high levels of energy consumed by the cells in order to maintain their integrity and activity, which drives to a lower energy utilization for growth [48]. The highest $Y_{H}$ value was measured in the biomass of SBR-2 at the end of Step-2. This 
increment could be due to the considerable increase in aeration time, which accelerated the metabolic processes in the cells including growth.

\section{CONCLUSIONS}

The hypersaline effluent from table olive processing can be successfully treated biologically in an aerobically operated SBR in spite of its high conductivity, COD and phenolic compounds. The COD and T.Ph. removal efficiencies of around $80 \%$ can be achieved.

It was proved that reducing the aeration time is possible without reducing the process efficiency. Coming from the completely aerobically operation of the SBR, the allocation of the reaction time in 8 hours of anaerobic phase and 14 hours of aerobic phase was not detrimental for the process. This implies a diminution in the energy consumption in view of the process implementation at a larger scale. In addition to this, the sludge production is reduced as a consequence of alternating anaerobic and oxic conditions.

The implementation of anaerobic times in the reaction higher than 8 hours led to process deterioration. For these conditions, a fast and progressive diminution in the COD removal efficiency occurs. However, the T.Ph. removal efficiency does not decrease in the same way, which means that phenolic compounds can be partially degraded anaerobically. On the other hand, respirometric measurements of both mixed liquors indicated that the SOUR increases linearly when the aerobic time in the SBR decreases.

\section{Acknowledgments.}

The authors of this work thank the financial support of CDTI (Centre for Industrial Technological Development) depending on the Spanish Ministry of Science and Innovation 


\section{References}

[1] Lefebvre O., Moletta R., Treatment of organic pollution in industrial saline wastewater: a literature review, Water Res. 40 (2006), 3671-3682.

[2] García-García P., López-López A., Moreno-Baquero J.M., Garrido-Fernández A., Treatment of wastewaters from the green table olive packaging industry using electrocoagulation, Chem. Eng. J. 170 (2011), 59-66.

[3] Moussavi G., Khavanin A., Alizadeh R., The integration of ozonation catalyzed with $\mathrm{MgO}$ nanocrystals and the biodegradation for the removal of phenol from saline wastewater, Appl. Catal. B Environ. 97 (2010), 160-167.

[4] Rivas F.J., Beltrán F.J, Gimeno O., Alvarez P., Optimisation of Fenton’s reagent usage as a pre-treatment for fermentation brines, J. Hazard. Mater. B96 (2003), 277-290.

[5] Lobo C.C., Bertola N.C., Contreras E.M., Stoichiometry and kinetic of the aerobic oxidation of phenolic compounds by activated sludge, Bioresour. Technol. 136 (2013), $58-65$.

[6] Kargi F., Dincer A.R., Effect of salt concentration on biological treatment of saline wastewater by fed-batch operation, Enzyme. Microb. Technol. 19 (1996), 529-537.

[7] Wang J.L., Zhan X.M., Feng Y.C., Qian Y., Effect of salinity variations on the performance of activated sludge system, Biomed. Environ. Sci. 18 (2005), 5-8.

[8] Chowdhury P., ViraraghavanT., Srinivasan A., Biological treatment processes for fish processing wastewater: a review, Bioresour. Technol. 101 (2010), 439-449. 
[9] Reid E., Liu X., Judd S.J., Effect of high salinity on activated sludge characteristics and membrane permeability in an immersed membrane bioreactor, J. Memb. Sci. 283 (2006), 164-171.

[10] Haddadi A., Shavandi M., Biodegradation of phenol in hypersaline conditions by Halomonas sp. strain PH2-2 isolated from saline soil, Int. Biodeterior. Biodegrad. 85 (2013), 29-34.

[11] Peyton B.M., Wilson T., Yonge D.R., Kinetics of phenol biodegradation in high salt solutions, Water Res. 36 (2002), 4811-4820.

[12] Ferrer-Polonio E., Mendoza-Roca J.A., Iborra-Clar A., Alonso-Molina J., PastorAlcañiz L., Comparison of two strategies for the start-up of a biological reactor for the treatment of hypersaline effluents from a table olive packaging industry, Chem. Eng. J. 273 (2015), 595-602.

[13] Malheiro R., Sousa A., Casal S., Bento A., Pereira J.A., Cultivar effect on the phenolic composition and antioxidant potential of stoned table olives, Food Chem. Toxicol. 49 (2011), 450-457.

[14] Bouaziz M., Lassoued S., Bouallagui Z., Synthesis and recovery of high bioactive phenolics from table-olive brine process wastewater, Bioorganic Med. Chem. 16 (2008), 9238-9246.

[15] Brenes M., Rejano L., Garcia P., Sanchez A., Garrido A., Biochemical changes in phenolic compounds during Spanish-style green olive processing, J. Agric. Food Chem. 43 (1995), 2702-2706. 
[16] Fendri I., Chamkha M., Bouaziz M., Labat M., Sayadi S., Abdelkafi S., Olive fermentation brine: biotechnological potentialities and valorization, Environ. Technol. 34 (2013), 1-13.

[17] Rieger L., Takács I., Siegrist H., Improving nutrient removal while reducing energy use at three Swiss WWTPs using advanced control, Water Environ. Res. 84(2) (2012), $170-188$.

[18] Descoins N., Deleris S., Lestienne, R., Trouvé E., Maréchal F., Energy efficiency in wastewater treatments plants: optimization of activated sludge process coupled with anaerobic digestion, Energy. 41 (2012), 153-164.

[19] Daw J., Hallett,K., DeWolfe J., Venner I., Energy efficiency strategies for municipal wastewater treatment facilities national renewable energy laboratory, Natl. Renew. Energy Lab. Golden, CO, USA (2012), 303.

[20] Spellman F., Handbook of water and wastewater treatment plant operations, CRC. Press, Boca Raton, USA (2008).

[21] Supaka N., Juntongjin K., Damronglerd S., Delia M., Strehaiano P., Microbial decolorization of reactive azo dyes in a sequential anaerobic-aerobic system, Chem. Eng. J. 99 (2004), 169-176.

[22] Kapdan I., Oztekin R., The effect of hydraulic residence time and initial COD concentration on color and COD removal performance of the anaerobic-aerobic SBR system, J. Hazard. Mater. 136(3) (2006), 896-901.

[23] Gerritse J., Gottschal J.C., Mineralization of the herbicide 2,3,6-trichlorobenzoic acid by a co-culture of anaerobic and aerobic bacteria, FEMS Microbiol. Lett. 101(2) (1992), 89-98. 
[24] Majumder P., Gupta S., Removal of chlorophenols in sequential anaerobic-aerobic reactors, Bioresour. Technol. 98 (2007), 118-129.

[25] Yang Z., Zhou S., The biological treatment of landfill leachate using a simultaneous aerobic and anaerobic (SAA) bio-reactor system, Chemosphere. 72 (2008), 1751-1756.

[26] Tartakovsky B., Manuel M.F., Guiot S.R., Degradation of trichloroethylene in a coupled anaerobic-aerobic bioreactor: modeling and experiment, Biochem. Eng. J. 26 (2005), 72-81.

[27] Othman N. B., Roblain D., Chammen N., Thonart P., Hamdi M., Antioxidant phenolic compounds loss during the fermentation of Chétoui olives, Food Chem. 116 (2009), 662-669.

[28] Kiai H., Hafidi A., Chemical composition changes in four green olive cultivars during spontaneous fermentation, LWT Food Sci. Technol. 57(2) (2014), 663-670.

[29] Ryan D., Robards K., Lavee S., Changes in phenolic content of olive during maturation, Int. J. Food Sci. Technol. 34 (1999), 265-274.

[30] APHA AWWA WEF. Standard methods for the examination of water and wastewater, 21st. ed. American Public Health Association, Washington, DC. (2005).

[31] Wesley Eckenfelder W., Petr Grau P.E., Activated sludge process desing and control theory and practice, Ed. Technomic Publishing AG, Lancaster, Pennsylvania, (1992), $56-159$.

[32] Singleton V., Orthofer R., Lamuela-Raventós R.M., Analysis of total phenols and other oxidation substrates and antioxidants by means of Folin-Ciocalteu reagent, Methods. Enzymol. 299 (1999), 152-178.

[33] El-Abbassi A., Khayet M., Hafidi A., Micellar enhanced ultrafiltration process for the 
treatment of olive mill wastewater, Water Res. 45 (2011), 4522-4530.

[34] Garcia-Ochoa F., Gomez E., Santos V.E., Merchuk J.C., Oxygen uptake rate in microbial processes: an overview, Biochem. Eng. J. 49 (2010), 289-307.

[35] Garcia-Ochoa F., Escobar S., Gomez E., Specific oxygen uptake rate as indicator of cell response of Rhodococcus erythropolis cultures to shear effects, Chem. Eng. Sci. 122 (2015), 491-499.

[36] Mineta R., Salehi Z., Yoshikawa H., Kawase Y., Oxygen transfer during aerobic biodegradation of pollutants in a dense activated sludge slurry bubble column: actual volumetric oxygen transfer coefficient and oxygen uptake rate in p-nitrophenol degradation by acclimated waste activated sludge, Biochem. Eng. J. 53 (2011), 266274.

[37] Parinos C.S., Stalikas C.D., Giannopoulos T.S., Pilidis G.A., Chemical and physicochemical profile of wastewaters produced from the different stages of Spanishstyle green olives processing, J. Hazard. Mater. 145 (2007), 339-343.

[38] Khursheed A., Sharma M.K., Tyagi V.K., Khan A.A., Kazmi A.A., Specific oxygen uptake rate gradient - Another possible cause of excess sludge reduction in oxicsettling-anaerobic (OSA) process, Chem. Eng. J. 281 (2015), 613-622.

[39] Chen G.H., An K.J., Saby S., Brois E., Djafer M., Possible cause of excess sludge reduction in an oxic-settling-anaerobic activated sludge process (OSA process), Water Res. 37 (2003), 3855-3866.

[40] Rodriguez-Perez S., Fermoso F.G., Influence of an oxic settling anoxic system on biomass yield, protozoa and filamentous bacteria, Bioresour. Technol. 200 (2016), $170-177$. 
[41] Chen G.H., Yip W.K., Mo H.K., Liu Y., Effect of sludge fasting/feasting on growth of activated sludge cultures, Water Res. 35 (2001), 1029-1037.

[42] Pinches A., Pallent L., Rate and yield relationships in the production of xanthan gum by batch fermentations using complex and chemically defined growth media, Biotechnol. Bioeng. 28 (1986), 1484-1496.

[43] Rosenkranz F., Cabrol L., Carballa M., Relationship between phenol degradation efficiency and microbial community structure in an anaerobic SBR, Water Res. 47 (17) (2013), 6739-6749.

[44] Wang J., Zhou Y., Li P., Lu H., Jin R., Liu G., Effects of redox mediators on anaerobic degradation of phenol by Shewanella sp. XB, Appl. Biochem. Biotechnol. 175 (2015), 3162-3172.

[45] Chen J.H., Wang Y., Kotsopoulos T.A., Kaparaju P., Zeng R.J., Development of an anaerobic co-metabolic model for degradation of phenol, m-cresol and easily degradable substrate, Biochem. Eng. J. 106 (2016), 19-25.

[46] Wang Z.C., Gao M.C., Ren Y., Effect of hydraulic retention time on performance of an anoxic-aerobic sequencing batch reactor treating saline wastewater, Int. J. Environ. Sci. Technol. 12 (2015), 2043-2054.

[47] Orhon D., Babuna F.G., Karahan O., Industrial wastewater treatment by activated sludge, IWA Publis., London, U.K. (2009).

[48] Hao X.D., Wang Q.L., Zhu J.Y., Van Loosdrecht M.C.M., Microbiological endogenous processes in biological wastewater treatment systems, Crit. Rev. Environ. Sci. Technol. 40 (2010), 239-265. 